DOI: $10.17951 / 1 r p .2018 .37 .4 .129-142$

\author{
MARIA CHODKOWSKa \\ Uniwersytet Marii Curie-Skłodowskiej w Lublinie \\ https://orcid.org/0000-0002-3931-3894 \\ ZDZISŁAW KaZANOWSKI \\ Uniwersytet Marii Curie-Skłodowskiej w Lublinie \\ https://orcid.org/0000-0002-2860-9817
}

\title{
ZNACZENIE ZMIANY POKOLENIOWEJ DLA OCEN KONSEKWENCJI POLSKIEJ TRANSFORMACJI
}

\begin{abstract}
Streszczenie: Opracowanie ma charakter literaturowo-empiryczny. Część literaturowa wprowadza w problemy upadku komunizmu w Polsce, rozpatrywane w kategoriach zjawisk i procesów społecznych. W części badawczej zaprezentowane zostały wyniki badań dotyczących oceny wpływu upadku komunizmu w Polsce na losy kraju i świata. Oceny tej dokonywały dwa pokolenia respondentów. W prezentacji wyników uwzględniono różnice wynikające z przynależności pokoleniowej. W badaniach zastosowano oryginalną procedurę wraz z autorskim narzędziem badawczym. Wyniki wykazały, że większość Polaków jest przekonana o pozytywnym wpływie polskiej transformacji zarówno na losy kraju, jak i na zmiany o zasięgu globalnym. Różnice pokoleniowe w dokonywanych ocenach były niewielkie, tylko sporadycznie kształtowały się na poziomie istotności statystycznej. Negatywne konsekwencje upadku komunizmu w Polsce wyrażało niewielu badanych. Przeważnie były to osoby reprezentujące pokolenie dorosłych, natomiast młodzież częściej niż dorośli nie dokonywała żadnych ocen. Na podstawie wyników badań można sformułować wniosek, że Polacy są przekonani o słuszności zmian po 1990 roku, a ich opinie o znaczeniu światowym tych zmian stanowią wyraz poczucia dumy z dokonań własnego narodu.
\end{abstract}

Słowa kluczowe: pokolenie, zmiana społeczna

\section{WPROWADZENIE}

Pokolenie i zmiana pokoleniowa stanowią kategorie pojęciowe o charakterze interdyscyplinarnym. Wprawdzie najmocniej związane są z teorią socjologiczną, jednak również i w pedagogice postrzeganie problemów wychowawczych przez pryzmat różnic pokoleniowych ma duże znaczenie, ponieważ pozwala na dokonywanie 
diagnoz z uwzględnieniem dynamiki tych problemów oraz kontekstu zdarzeń różnej natury charakterystycznych dla danego pokolenia.

Analizy zmian pokoleniowych najczęściej są odnoszone do różnic między dwoma następującymi po sobie pokoleniami w zakresie ich wartości, potrzeb, aspiracji czy oczekiwań. Różnice te stają się przyczynami sprzeczności i napięć określanych jako konflikty pokoleń. Józef Chałasiński (1984, s. 184) w wydanym w roku 1938 Młodym pokoleniu chłopów pisał o tym następująco: „Konflikt [...] pomiędzy młodymi i starymi wyraża się nie tylko w odmienności postaw i dążności społecznych tych pokoleń, lecz także w odrębności struktur społecznych, ku którym pokolenia te ciążą w swoich postawach”. Maria Ossowska (1986, s. 35-36) charakteryzowała młodych jako dążących do zaspokajania własnych namiętności, odnoszenia sukcesów, dominowania nad innymi, ale równocześnie jako ufnych, bo jeszcze nieobciążonych przeżytymi rozczarowaniami, bardziej niż starzy odważnych i skierowanych ku przyszłości.

Różnice między kolejnymi pokoleniami przekładają się na wartości, cele, a także działania. Pokolenie młodych tworzy własny świat społeczny, inny od świata społecznego poprzedniego pokolenia. Różnice między tymi światami wyznaczają charakter i rozmiary zmiany pokoleniowej, ale podstawą każdego z nich są preferencje aksjologiczne.

W klasycznych koncepcjach Helmuta Klagesa i Rolanda Ingleharta zmiana pokoleniowa ściśle wiąże się ze zmianami wartości. Preferencje wartości utrwala sytuacja społeczno-ekonomiczna, w jakiej dane pokolenie wzrastało. Szczególnie ceni się wartości, które w tym okresie były niedostępne (za: Adamczyk 2014).

Teoretycznie nietrudno określić orientacyjne przedziały między kolejnymi pokoleniami, natomiast wyodrębnianie konkretnych grup wiekowych, ustalanie ostrych granic między nimi nie jest już łatwe, a wręcz staje się możliwe. Socjologowie szukają w związku z tym kryteriów innych niż rok urodzenia przy świadomości, że nie mogą one być tak ścisłe jak daty i liczby. Karl Mannheim (1992, s. 156) pisze, że pokolenie obejmuje osoby urodzone w podobnym czasie, wzrastające w tych samych uwarunkowaniach społecznych i kulturowych, co przekłada się na podobne sposoby myślenia i postawy wobec określonych wartości, pod warunkiem świadomego zaangażowania w idee czy wydarzenia ważne $\mathrm{w}$ danym czasie i miejscu. Znaczenie „podobnego” czasu jest nieostre, natomiast mówienie o „tych samych uwarunkowaniach społecznych i kulturowych" zawiera pewien większy bądź mniejszy - stopień uogólnienia, ponieważ każda grupa pokoleniowa jest zróżnicowana ze względu na przynależność klasową, warstwową, religijną czy etniczną.

Z uwagi na wskazane wyżej trudności definicyjne rozróżnianie pokoleń, a konkretnie granic czasowych między nimi jest bardzo trudne. Socjologowie 
wprowadzają dodatkowe kryteria podziałów, bardziej czytelne i łatwiejsze do zdefiniowania. W określonych okresach można zlokalizować wydarzenie bądź ciąg wydarzeń, które wywołały w danej grupie tak silne przeżycia, że nie są w stanie wymazać ich z pamięci i, co więcej, przez pryzmat tych przeżyć postrzegają zdarzenia późniejsze. Są to przeżycia pokoleniowe (Garewicz 1983, s. 77). Biorąc pod uwagę ich znaczenie, Piotr Sztompka (2005, s. 175) pisze, że pokolenie to

zbiorowość ludzi, którzy choć osobno i niezależnie od siebie, doświadczyli takich samych ważnych wydarzeń historycznych, przeżyli te same sytuacje i reagowali na te same wyzwania, co znalazło wyraz w ich przekonaniach, regułach i wartościach oraz wytworzyło poczucie wspólnego losu.

Jednocześnie autor zauważa (Sztompka 2005, s. 154), iż to samo doświadczenie każdy odbiera nieco inaczej, reaguje na nie w sposób indywidualny, ale przy świadomości, że podobnie zachowuje się wielu innych, że nie jest sam. Sztompka nazywa to podobieństwem biografii i stwierdza: „ten paralelizm przeżyć, mimo że doznawanych w różnych miejscach, różnych momentach i z różną intensywnością, [jest] ważn[y] także dlatego, że trwale kształtuj[e] mentalność, postawy, hierarchię wartości uczestników”, w związku z czym wytwarza „wspólnotę pokoleniową opartą na pamięci przeżytych wydarzeń" (Sztompka 2005, s. 155).

W losach współczesnych dorosłych Polaków takie wydarzenia były co najmniej trzy. Pierwsze z nich to głęboka trauma stanu wojennego, drugie to radość z wyboru rodaka na Stolicę Piotrową, a trzecie, które w sposób najbardziej widoczny i wielowymiarowy zmieniło ich życie, to polska transformacja ustrojowa z 1989 roku. Analizy prezentowane w artykule odnoszą się do tego ostatniego. Opierają się na założeniu, że można mówić o różnicach pokoleniowych między Polakami, którzy w przełomowym roku byli już dorośli bądź dorastający, tzn. mogli kierować dokonującymi się przemianami bądź identyfikować się z nimi, a pokoleniem ich dzieci, które dorastało w rzeczywistości posttransformacyjnej.

W 1989 roku oficjalnie przestała istnieć Polska Rzeczpospolita Ludowa, potocznie zwana PRL-em. Nazwę tę wprowadzono konstytucyjnie w 1952 roku dla państwa polskiego utworzonego po zakończeniu okupacji hitlerowskiej w nowych granicach terytorialnych, na mocy dekretu PKWN-u - tymczasowej władzy konstruującej struktury wyznaczone dyktatem Związku Radzieckiego. Charakterystyczne dla Polskiej Rzeczpospolitej Ludowej były brak zasad demokratycznych oraz skoncentrowanie władzy w jednej, odgórnie powołanej partii komunistycznej, przy czym ciągłość tej władzy gwarantowały przymus i represje. Życie gospodarcze zostało podporządkowane zasadom centralnym, podobnie jak życie społeczne i polityczne, a przejawy demokracji i sprzeciwu wobec łamania praw 
człowieka skutecznie (przynajmniej do pewnego czasu) eliminowały cenzura oraz współdziałający z nią mocno rozbudowany aparat represyjny. $\mathrm{W}$ takich warunkach dorastało kilka pokoleń Polaków: powojenne pokolenie entuzjastów nowych szans edukacyjnych i zawodowych dla młodzieży robotniczo-chłopskiej' ${ }^{1}$, pokolenie rodzących się struktur demokratyczno-wolnościowych naznaczonych wydarzeniami marca 68. i grudnia 70. i wreszcie pokolenie ruchów solidarnościowych zakończonych transformacją ustrojową.

Wraz z upływem czasu kolejne pokolenia Polaków w coraz większym stopniu przeżywały rozczarowanie brakiem oczekiwanych efektów gospodarczych powiązane z potęgującym się poczuciem ubezwłasnowolnienia, które wynikało zarówno z podporządkowania Związkowi Radzieckiemu, jak i z podlegania autorytarnej władzy wewnętrznej. Jednocześnie coraz więcej doświadczeń krajów rozwijających się w warunkach wolnego rynku i demokratycznych stosunków społecznych przenikało przez uszczelniające się granice bloku wschodniego nazywane „żelazną kurtyną". W tych warunkach opozycja polityczna znajdowała oparcie w szerokich kręgach społecznych, zarówno inteligenckich i młodzieżowych, jak i robotniczych, a kryzysy gospodarcze stawały się bodźcem do uzewnętrzniania coraz bardziej „zorganizowanego" masowego niezadowolenia i protestu. Narodził się wówczas wielomilionowy ruch społeczny, który przeszedł do historii jako „Solidarność”. Jego zwycięstwo zapoczątkowało przemiany gospodarcze i społeczno-polityczne, a przy tym stało się powszechnie utożsamiane z upadkiem komunizmu w Polsce.

Ostatnie z pokoleń Polski Ludowej dorastało w latach 80., doświadczając zarówno euforii kolejnych, cząstkowych zwycięstw nad reżimem, jak i porażek solidarnościowych zrywów. Na bazie osobistych doświadczeń tego pokolenia rozgrywał się wielki przełom 1989 roku. Kolejna generacja dorastała już w warunkach posttransformacyjnych, co spowodowało wyraźne zróżnicowanie przeżyć pokoleniowych wiążących się ze zmianą społeczną, która jest przez nas traktowana jako kategoria badawcza służąca „do oznaczania tego fragmentu przedmiotu badań, który umożliwia zaistnienie zmiany w jednostce jako indywidualności ludzkiej” (za: Gnitecki 2007, s. 244).

${ }^{1}$ Dla zrozumienia tego entuzjazmu ważny jest kontekst Polski przedwojennej. Rzesze jej mieszkańców, zwłaszcza chłopów na wsi i bezrobotnych w mieście, pozbawione były nie tylko szans na edukację i rozwój, ale w ogóle na zapewnienie sobie i rodzinie minimum warunków niezbędnych do przetrwania nawet w sensie biologicznym. Ten palący problem społeczny został udokumentowany głównie w socjologicznych edycjach pamiętnikarskich (Krzywicki 1933, 1935), które po przetłumaczeniu na wiele języków wstrząsnęły ówczesna Europą. 


\section{BADANIA WŁASNE}

Koncepcja badań, których wyniki będą prezentowane w niniejszym opracowaniu, odwołuje się do teorii zmiany społecznej ${ }^{2}$. Transformacje, jakie dokonały się na przestrzeni ostatnich dekad w Polsce, pozwalają na wyznaczenie przedziałów pokoleniowych. Możliwe są określenie różnic między pokoleniami w zakresie postaw, wartości i oczekiwań, a także ocena realiów życia społecznego, gospodarczego i kulturalnego zarówno przez uczestników, jak i przez kolejne pokolenie, które nie ma osobistych doświadczeń związanych z tamtymi wydarzeniami.

Ponieważ o rzeczywistych efektach zmiany w każdym przypadku decyduje społeczeństwo, ze względów poznawczych ważna wydaje się nie tylko sama zmiana, ale przede wszystkim percepcja tej zmiany w różnych kręgach, kategoriach i grupach społecznych. Uwzględniając powyższe aspekty, za cel podjętych badań uznano opisanie różnic międzypokoleniowych w zakresie percepcji polskiej transformacji ustrojowej. Przyjęte zostało założenie, że wiek wyznacza różnice w percepcji konsekwencji zmiany ustrojowej. Rozgranicza on pokolenie, które miało możliwość wpływu na kształtowanie ówczesnych realiów życia społecznego, a zwłaszcza na osłabianie negatywnych skutków zmiany i wzmacnianie jej konsekwencji pozytywnych, od pokolenia, które takiego wpływu już nie miało, w związku z czym nie czuje się odpowiedzialne za następstwa transformacji, a co więcej odpowiedzialnością obciąża pokolenie rodziców.

Badania zostały zlokalizowane w paradygmacie orientacji pozytywistycznej, co wyznacza ich charakter kwantytatywny (Krüger 2007, s. 174). Jak pisze Tadeusz Pilch (2010, s. 66), „w badaniach ilościowych cel badań jest wyraźnie określony przed ich rozpoczęciem”. W związku z tym na początku poszukiwań sformułowano problem badawczy, który miał charakter diagnostyczny i został wyrażony za pomocą pytania: jakie różnice w percepcji konsekwencji polskiej transformacji ustrojowej dla losów kraju i świata występują między rodzicami dorastającymi przed 1989 rokiem a ich dziećmi?

Jako metodę w procedurze badawczej przyjęto sondaż diagnostyczny, co pozwoliło na zgromadzenie wiedzy odnoszącej się do badanego zjawiska w postaci wyrażanych na jego temat opinii oceniających. Techniką badawczą była ankieta zawierająca wyskalowane listy twierdzeń na temat różnych obszarów konsekwencji zmiany społecznej.

W doborze grupy badanej posłużono się dwoma kryteriami. Pierwszym było pełnienie roli pracownika socjalnego przez respondentów reprezentujących pokolenie

${ }^{2}$ Zmiana społeczna jest tu rozumiana jako zmiana odnosząca się wyłącznie do struktur społecznych, stanowiąca różnicę między stanem systemu społecznego (grupy, organizacji) w jednym momencie a stanem tego samego systemu w innym momencie (zob. Sztompka 2005, s. 453). 
przedtransformacyjne. Taki dobór populacji wynikał z faktu, iż pracownicy socjalni należą do grup zawodowych mających stosunkowo duże możliwości oddziaływania na konsekwencje zmiany społecznej. Do obowiązków konstytuujących ich role zawodowe przypisane jest przeciwdziałanie negatywnym skutkom zmian zagrażających marginalizacją, wykluczeniem jednostek i grup nieradzących sobie z sytuacjami trudnymi wygenerowanymi przez zmianę o różnym natężeniu, a zwłaszcza przez kryzys rozumiany jako zmiana gwałtowna.

Drugie kryterium, jakie zostało uwzględnione w doborze próby, dotyczyło respondentów młodszych. Do tej grupy włączono młodzież uczęszczającą do szkół ponadgimnazjalnych - dzieci rodziców tworzących populację starszą.

Kierując się dwoma powyższymi kryteriami, znajdującymi uzasadnienie w przedmiocie analizy, przeprowadzono badania w grupie pracowników socjalnych różnych regionów Polski (o wysokim, przeciętnym i niskim poziomie rozwoju gospodarczego) oraz w grupie ich dzieci - uczniów szkół ponadgimnazjalnych. Taki dobór badanych grup powinien znaleźć odzwierciedlenie w uzyskanych wynikach, co zostanie poddane weryfikacji we wnioskach końcowych.

W badaniach uczestniczyło 245 rodziców (w tym 181 matek oraz 64 ojców) oraz ich dzieci w okresie adolescencji (177 dorastających kobiet i 68 dorastających mężczyzn). W sumie badania objęły 490 osób. Średnia wieku rodziców wynosiła 45,05 roku, natomiast średnia wieku młodzieży - 17,37 roku.

Badani reprezentowali trzy typy środowiska zamieszkania: wieś (93 rodziny $-37,96 \%$ ), małe miasto (90 rodzin - 36,73\%) i duże miasto powyżej 50 tysięcy mieszkańców (62 rodziny - 25,31\%). Rodzice posiadali częściej wykształcenie wyższe (153 osoby - 62,45\%), rzadziej średnie (90 osób - 36,73\%). Dwie osoby $(0,82 \%)$ nie udzieliły informacji na ten temat.

Jeśli chodzi o stosunek do wiary i Boga, 222 dzieci (90,61\%) oraz 235 rodziców $(95,92 \%)$ zadeklarowało się jako wierzący, podczas gdy 17 dzieci $(6,94 \%)$ i 9 rodziców $(3,67 \%)$ jako niewierzący. Sześcioro dzieci $(2,45 \%)$ i jeden rodzic $(0,41 \%)$ nie odpowiedzieli na to pytanie. Wyniki analizy testem Chi (z uwzględnieniem braku odpowiedzi) wykazały obecność istotnej statystycznie różnicy miedzy badanymi grupami pokoleniowymi $(\mathrm{p}<0,05)$. Wynik taki sugeruje, iż należy brać pod uwagę stosunek do wiary i religii jako zmienną mogącą oddziaływać na różnice międzypokoleniowe dotyczące badanych problemów.

\section{WYNIKI BADAŃ}

Wyniki prezentowane w tej części opracowania dotyczą postrzegania przez dwa pokolenia Polaków konsekwencji transformacji ustrojowej z 1989 roku dla losów 
kraju i świata. Badani oceniali najpierw zmiany w zakresie sytuacji bytowej Polaków, sytuacji politycznej Polski, moralności Polaków, ich wiedzy, religijności, jakości stosunków z innymi ludźmi, tolerancji oraz aktywności życiowej. Szczegółowe dane na ten temat, z uwzględnieniem zróżnicowań pokoleniowych, zawiera tabela 1.

Tabela 1. Pokoleniowość a percepcja konsekwencji transformacji ustrojowej dla kraju

\begin{tabular}{|l|c|c|c|c|c|c|}
\hline \multirow{2}{*}{ Obszary zmiany } & \multicolumn{2}{c|}{$\begin{array}{c}\text { Pokolenie } \\
\text { dzieci }\end{array}$} & \multicolumn{2}{c|}{$\begin{array}{c}\text { Pokolenie } \\
\text { rodziców }\end{array}$} & \multirow{2}{*}{ Test F } & \multirow{2}{*}{ Test T } \\
\cline { 2 - 6 } & $\mathbf{M d z}$ & SDdz & Mr & SDr & & \\
\hline 1 - zmiana sytuacji bytowej Polaków & 2,40 & 2,01 & 1,98 & 2,27 & 0,057 & 0,031 \\
\hline 2 - zmiana sytuacji politycznej Polski & 2,80 & 1,87 & 2,61 & 2,06 & 0,140 & 0,298 \\
\hline 3 - zmiana moralności Polaków & 1,80 & 1,76 & 1,47 & 2,32 & 0,000 & 0,078 \\
\hline 4 - zmiana wiedzy Polaków & 1,95 & 1,72 & 2,14 & 1,71 & 0,901 & 0,224 \\
\hline 5 - zmiana religijności Polaków & 1,42 & 1,80 & 1,23 & 1,88 & 0,455 & 0,267 \\
\hline $\begin{array}{l}\text { 6 - zmiana stosunków między ludźmi } \\
\text { w Polsce }\end{array}$ & 1,62 & 1,89 & 1,29 & 2,05 & 0,233 & 0,069 \\
\hline 7 - zmiana tolerancji Polaków & 1,38 & 1,81 & 1,22 & 1,88 & 0,552 & 0,325 \\
\hline $\begin{array}{l}\text { 8 - zmiana aktywności życiowej } \\
\text { Polaków }\end{array}$ & 1,79 & 1,81 & 1,80 & 1,92 & 0,381 & 0,949 \\
\hline
\end{tabular}

Badane pokolenia wykazały stosunkowo dużą zgodność w ocenie konsekwencji transformacji ustrojowej dla życia ogółu Polaków, bowiem tylko w jednym z ocenianych obszarów różnice osiągnęły poziom istotności statystycznej (zmiana sytuacji bytowej Polaków: $\mathrm{p}<0,05$ ), a w dwóch innych zbliżyły się do tego poziomu (zmiana stosunków między ludźmi w Polsce oraz zmiana moralności Polaków). Średnie uzyskane w grupie młodzieży były wyższe od średnich w grupie rodziców niemal we wszystkich badanych obszarach wpływu. Wyższe średnie dorośli osiągnęli tylko w zakresie zmiany wiedzy Polaków (różnica między średnimi wynosi: M1 - M2 = -0,19) oraz zmiany aktywności życiowej Polaków (M1 - M2 = -0,01). Szczegółowych informacji na temat omawianych zróżnicowań pokoleniowych dostarcza tabela 2. 
Tabela 2. Pokoleniowość a rozkład pozytywnych i negatywnych ocen konsekwencji transformacji ustrojowej dla polskiego społeczeństwa

\begin{tabular}{|c|c|c|c|c|c|c|c|c|c|c|c|c|c|c|c|c|}
\hline \multirow{3}{*}{ 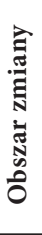 } & \multicolumn{8}{|c|}{ Pokolenie dzieci } & \multicolumn{8}{|c|}{ Pokolenie rodziców } \\
\hline & \multicolumn{2}{|c|}{ 苞 } & \multicolumn{2}{|c|}{ 光 } & \multicolumn{2}{|c|}{ 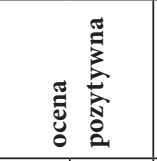 } & \multicolumn{2}{|c|}{ 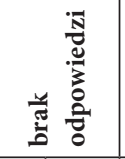 } & \multicolumn{2}{|c|}{ 苞 } & \multicolumn{2}{|c|}{ 光 } & \multicolumn{2}{|c|}{ 范 } & \multicolumn{2}{|c|}{ 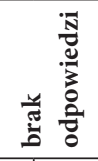 } \\
\hline & $\mathbf{N}$ & $\%$ & $\mathbf{N}$ & $\%$ & $\mathbf{N}$ & $\%$ & $\mathbf{N}$ & $\%$ & $\mathbf{N}$ & $\%$ & $\mathbf{N}$ & $\%$ & $\mathbf{N}$ & $\%$ & $\mathbf{N}$ & $\%$ \\
\hline 1 & 14 & 5,71 & 26 & 10,61 & 200 & 81,63 & 5 & 2,04 & 33 & 13,47 & 17 & 6,94 & 193 & 78,78 & - & 0,82 \\
\hline 2 & 6 & 2,45 & 22 & 98 & 212 & 86,53 & 5 & 2,04 & 15 & & 21 & 8,57 & 207 & 84,49 & 2 & 0,82 \\
\hline 3 & 5 & 2,04 & 65 & 6,53 & 17 & 69,39 & 5 & 2,04 & 26 & 10,61 & 35 & 27,00 & $15 /$ & 64,08 & 2 & 0,82 \\
\hline 4 & 4 & 1,63 & 54 & 2,04 & 182 & 74,29 & 5 & 2,04 & 7 & 2,857 & 37 & 15,10 & 199 & 81,22 & 2 & 0,82 \\
\hline 5 & 9 & 3,67 & 97 & 39,59 & 134 & 54,69 & 5 & 2,04 & 26 & 10,61 & 74 & 30,20 & 143 & 58,37 & 2 & 0,82 \\
\hline 6 & 13 & 5,31 & 60 & 24,49 & 166 & 67,76 & 5 & 2,04 & 33 & 13,47 & 62 & 25,31 & 148 & 60,41 & 2 & 0,82 \\
\hline 7 & 7 & 2,86 & 100 & 40,82 & 133 & 54,29 & 5 & 2,04 & 26 & 10,61 & 68 & 27,76 & 149 & 60,82 & 2 & 0,82 \\
\hline 8 & 6 & 2,45 & 75 & 30,61 & 159 & 64,90 & 5 & 2,04 & 10 & 4,082 & 61 & 24,90 & 172 & 70,20 & 2 & 0,82 \\
\hline
\end{tabular}

Oznaczenia: 1 - zmiana sytuacji bytowej Polaków, 2 - zmiana sytuacji politycznej Polski, 3 - zmiana moralności Polaków, 4 - zmiana wiedzy Polaków, 5 - zmiana religijności Polaków, 6 - zmiana stosunków między ludźmi w Polsce, 7 - zmiana tolerancji Polaków, 8 - zmiana aktywności życiowej Polaków.

Dane w poprzedniej tabeli wykazały, że średnia ocen wpływu transformacji ustrojowej dla sytuacji ogółu Polaków we wszystkich poddanych analizie obszarach ma wartość dodatnią. Z kolei analiza indywidualnych wypowiedzi zawartych w powyższej tabeli wykazuje, że dostrzeganie pozytywnych konsekwencji tego czynnika przekracza $50 \% \mathrm{w}$ odniesieniu do wszystkich obszarów zmiany. W grupie rodziców najwięcej wskazań pozytywnych otrzymały: zmiana sytuacji politycznej i zmiana wiedzy Polaków (powyżej 80\%), a najmniej - zmiany religijności Polaków i ich tolerancji oraz poprawa stosunków międzyludzkich (w granicach 60\%). Z kolei młodzież najwięcej zmian pozytywnych wiążących się z transformacją ustrojową w Polsce odnosiła do poprawy sytuacji bytowej Polaków oraz sytuacji politycznej Polski (powyżej 80\%), a najmniej - do wzrostu religijności Polaków i ich tolerancji. Zatem różnice między badanymi pokoleniami w zakresie percepcji pozytywnych konsekwencji transformacji ustrojowej w Polsce to przede wszystkim częstsze wskazywanie poprawy warunków bytowych przez młodych i częstsze wskazywanie poprawy poziomu wiedzy przez starszych respondentów. Reprezentanci obydwu grup pokoleniowych byli zgodni w sceptycznym postrzeganiu ewentualnej poprawy religijności i tolerancji Polaków, chociaż i tutaj korzystne zmiany dostrzegła więcej niż połowa badanych.

Stosunkowo rzadkie okazało się wiązanie transformacji ustrojowej w Polsce z negatywnymi konsekwencjami tego czynnika zmiany społecznej, zwłaszcza w grupie młodzieży, gdzie wskazania negatywne nie osiągnęły procentowej wartości dwu- 
cyfrowej w odniesieniu do żadnego z obszarów wpływu. Najczęściej konsekwencje negatywne uczniowie wiązali ze zmianą sytuacji bytowej oraz zmianą stosunków międzyludzkich (w granicach 5,5\%), a najrzadziej - ze zmianą wiedzy Polaków (poniżej 2\%) oraz zmianą ich moralności (2\%). W pokoleniu rodziców wskaźnik negatywnej oceny przekroczył 10\% w obszarach zmiany sytuacji bytowej Polaków, ich moralności, religijności, tolerancji oraz zmiany stosunków międzyludzkich, natomiast nie przekroczył tego progu w zakresie wiedzy Polaków i ich życiowej aktywności (poniżej 5\%). Zatem dorośli zdecydowanie częściej niż młodzież formułowali negatywne oceny konsekwencji transformacji ustrojowej w Polsce, i dotyczy to wszystkich uwzględnionych obszarów wpływu, natomiast młodzież była bardziej skłonna od dorosłych do wskazywania na brak wpływu analizowanego zdarzenia na wymienione obszary. Ponadto młodzi respondenci znacznie rzadziej niż rodzice wyrażali silne emocje wobec ocenianych konsekwencji transformacji poprzez wybory skrajnych wariantów odpowiedzi na skali zastosowanej w badaniach (+5 i -5$)$.

Transformacja ustrojowa w Polsce był wydarzeniem na miarę światową i wiązała się ściśle z innymi zdarzeniami współdecydującymi o rozpadzie bloku wschodniego. Wczesna inicjatywa Polski w tym zakresie stanowiła dla większości Polaków żyjących okresie PRL-u powód do dumy narodowej. Kierując się tymi przesłankami, w badaniach uwzględniono również ocenę konsekwencji transformacji ustrojowej w Polsce dla zmian światowych dokonywaną przez pokolenie, które uczestniczyło w tamtych zdarzeniach i pokolenie znające ich przebieg tylko z przekazów pośrednich. Różnice przedstawia tabela 3.

Tabela 3. Pokoleniowość a percepcja konsekwencji transformacji ustrojowej dla świata

\begin{tabular}{|l|c|c|c|c|c|c|}
\hline \multirow{2}{*}{ Obszary zmiany } & \multicolumn{2}{c|}{$\begin{array}{c}\text { Pokolenie } \\
\text { dzieci }\end{array}$} & \multicolumn{2}{c|}{$\begin{array}{c}\text { Pokolenie } \\
\text { rodziców }\end{array}$} & \multirow{2}{*}{ Test F } & \multirow{2}{*}{ Test T } \\
\cline { 2 - 5 } & $\mathbf{M d z}$ & $\mathbf{S D d z}$ & $\mathbf{M r}$ & SDr & \\
\hline $\begin{array}{l}\text { 1 - zmiana sytuacji bytowej } \\
\text { najbiedniejszych krajów, regionów, grup }\end{array}$ & 1,37 & 1,8 & 1,17 & 1,89 & 0,661 & 0,248 \\
\hline $\begin{array}{l}\text { 2 - zmiana losu chorych } \\
\text { i niepełnosprawnych }\end{array}$ & 1,04 & 1,7 & 0,83 & 1,83 & 0,249 & 0,192 \\
\hline $\begin{array}{l}\text { 3 - zmiana stosunków między różnymi } \\
\text { grupami wyznaniowymi }\end{array}$ & 1,01 & 1,6 & 1,10 & 1,66 & 0,410 & 0,520 \\
\hline $\begin{array}{l}4 \text { - zmiana nasilenia konfliktów zbrojnych } \\
\text { na świecie }\end{array}$ & 0,94 & 1,6 & 0,81 & 1,67 & 0,834 & 0,400 \\
\hline $\begin{array}{l}\text { 5 - zmiany techniczno-cywilizacyjne } \\
\text { w świecie i rozwój nauki }\end{array}$ & 1,46 & 1,8 & 1,57 & 1,73 & 0,862 & 0,482 \\
\hline $\begin{array}{l}\text { 6 - zmiany w kulturze: wielokulturowość } \\
\text { i wieloetniczność }\end{array}$ & 1,36 & 1,7 & 1,36 & 1,69 & 0,651 & 0,994 \\
\hline
\end{tabular}


W ocenach dorosłych i młodzieży dotyczących wpływu polskiej transformacji ustrojowej na sytuację światową w odniesieniu do żadnego $\mathrm{z}$ uwzględnionych obszarów nie stwierdzono różnic statystycznie istotnych czy nawet zbliżających się do takiego poziomu. Zarówno w jednej, jak i drugiej grupie pokoleniowej średnie obliczone dla tych zmian były bardzo niskie, kształtowały się na poziomie poniżej 2,0. Badana młodzież najniżej oceniała wpływ transformacji polskiej na zmianę nasilenia konfliktów zbrojnych na świecie $(\mathrm{Mdz}=0,94)$, a najwyżej - na zmiany techniczno-cywilizacyjne w świecie i rozwój nauki. Prawdopodobnie podstawą takich ocen było zgodne z rzeczywistością przeświadczenie, że transformacja stworzyła możliwości włączania się polskich naukowców w programy międzynarodowe i wnoszenia ważnego wkładu w efekty ich realizacji.

Pokolenie rodziców także najczęściej dostrzegało pozytywny wpływ transformacji ustrojowej w Polsce na zmiany techniczno-cywilizacyjne w świecie i rozwój nauki $(\mathrm{Mr}=1,57)$, a najrzadziej - na zmianę nasilenia konfliktów zbrojnych na świecie $(\mathrm{Mr}=0,81)$ oraz zmianę losu chorych i niepełnosprawnych $(\mathrm{Mr}=0,83)$. Zwrócenie uwagi na tę ostatnią kwestię może być konsekwencją orientacji zawodowej, ale także nieco większej wrażliwości na problemy osób z utrudnieniami zdrowotnymi, charakterystycznej raczej dla starszych niż dla młodych.

Zróżnicowania ocen ze znakiem dodatnim i ujemnym bądź zerowym, stanowiące podstawę obliczania powyższych średnich, prezentuje tabela 4.

Tabela 4. Pokoleniowość a rozkład pozytywnych i negatywnych ocen konsekwencji transformacji ustrojowej dla polskiego społeczeństwa

\begin{tabular}{|c|c|c|c|c|c|c|c|c|c|c|c|c|c|c|c|c|}
\hline \multirow{3}{*}{ 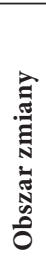 } & \multicolumn{8}{|c|}{ Pokolenie dzieci } & \multicolumn{8}{|c|}{ Pokolenie rodziców } \\
\hline & \multicolumn{2}{|c|}{ 卺 } & \multicolumn{2}{|c|}{ 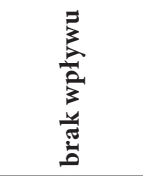 } & \multicolumn{2}{|c|}{ 逽 } & \multicolumn{2}{|c|}{ 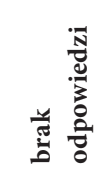 } & \multicolumn{2}{|c|}{ 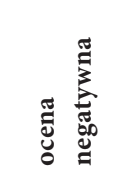 } & \multicolumn{2}{|c|}{ 总 } & \multicolumn{2}{|c|}{ 总 } & \multicolumn{2}{|c|}{ 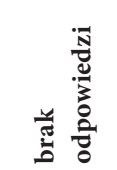 } \\
\hline & $\mathbf{N}$ & $\%$ & $\mathbf{N}$ & $\%$ & $\mathbf{N}$ & $\%$ & $\mathbf{N}$ & $\%$ & $\mathbf{N}$ & $\%$ & $\mathbf{N}$ & $\%$ & $\mathbf{N}$ & $\%$ & $\mathbf{N}$ & $\%$ \\
\hline 1 & 9 & 3,6 & 84 & 34,2 & 148 & 60,4 & 4 & 1,63 & 18 & 7,35 & 81 & 3,06 & 144 & 58,78 & 2 & 0,82 \\
\hline 2 & 11 & 4,49 & 105 & 42,86 & 125 & 51 & 4 & 1,63 & 23 & 9,39 & 97 & 39,59 & 123 & 50,20 & 2 & 0,82 \\
\hline 3 & 6 & 2,45 & 118 & 48,16 & 11 & 47,3 & 5 & 2,04 & 13 & 5,31 & 94 & 8,37 & 136 & 55,51 & 2 & 0,82 \\
\hline 4 & 16 & 6,5 & 108 & 44,08 & 117 & 47,8 & 4 & 1,63 & 18 & 7,35 & 114 & 6,53 & 111 & 45,31 & 2 & 0,82 \\
\hline 5 & 2 & 0,82 & 93 & 37,96 & 146 & 59,6 & 4 & 1,63 & 3 & 1,22 & 83 & 33,88 & 157 & 64,08 & 2 & 0,82 \\
\hline 6 & 3 & 1,22 & 99 & 40,41 & 139 & 56,7 & 4 & 1,63 & 5 & 2,04 & 85 & 34,69 & 153 & 62,45 & 2 & 0,82 \\
\hline
\end{tabular}

Oznaczenia: 1 - zmiana sytuacji bytowej najbiedniejszych krajów, regionów, grup, 2 - zmiana losu chorych i niepełnosprawnych, 3 - zmiana stosunków między różnymi grupami wyznaniowymi, 4 - zmiana nasilenia konfliktów zbrojnych na świecie, 5 - zmiany techniczno-cywilizacyjne w świecie i rozwój nauki, 6 - zmiany w kulturze: wielokulturowość i wieloetniczność. 
O wartości średnich ocen zarówno w grupie młodzieży, jak i w grupie rodziców zadecydowały przede wszystkim wskazania pozytywne dotyczące wpływu transformacji ustrojowej w Polsce na różne obszary sytuacji światowej. Młodzież najczęściej takie oceny formułowała wobec zmiany sytuacji bytowej najbiedniejszych krajów, regionów i grup (60,4\%), a najrzadziej w odniesieniu do zmiany stosunków między różnymi grupami wyznaniowymi (47,3\%). Natomiast najwięcej dorosłych pozytywny wpływ polskiej transformacji dostrzegało w obszarze zmian techniczno-cywilizacyjnych i rozwoju nauki na świecie (64,8\%), a najmniej w obszarze konfliktów zbrojnych na świecie $(45,31 \%)$. Tłumaczenie takich zróżnicowań ocen między pokoleniami sprawia trudność, ponieważ są one stosunkowo niewielkie, natomiast ogół wyników obejmujących wskazania pozytywne potwierdza, że większość Polaków wyraża przekonanie o pozytywnym wpływie polskiej transformacji na zmiany o zasięgu globalnym. Oceny negatywne były stosunkowo rzadkie, w żadnym z uwzględnionych obszarów nie zbliżały się nawet do $10 \%$ w grupie młodzieży, a w grupie rodziców pułap taki osiągnęły tylko w jednym zakresie (niekorzystnych zmian losu osób chorych i niepełnosprawnych). Prawdopodobnie pracownicy socjalni uwzględniali rosnące kręgi osób niepełnosprawnych i chorych z terenu całego byłego bloku wschodniego, którzy stracili znaczną część przywilejów wraz z upadkiem państwa opiekuńczego.

Niedostrzeganie jakichkolwiek powiązań między transformacją ustrojową w Polsce a zmianami globalnymi było stosunkowo częste (w granicach 40\%) tak w grupie dorosłych, jak i młodzieży (tu nieco częstsze). Charakterystyczne dla młodzieży okazało się także rzadsze formułowanie ocen skrajnych (+5 i -5) na zastosowanej w badaniach skali.

\section{DYSKUSJA WYNIKÓW I PODSUMOWANIE}

Transformacja ustrojowa z 1989 roku zapoczątkowała w Polsce gruntowne zmiany o szczególnym znaczeniu zarówno ze względu na rozległość i doniosłość ich konsekwencji, jak i udział narodu w ich kreowaniu. Była rozłożona w czasie, ogarniała coraz liczniejsze kręgi opozycjonistów i wiązała się z coraz bardziej radykalnymi działaniami wyrażającymi sprzeciw wobec starego porządku, niezgodnego z potrzebami i oczekiwaniami społeczeństwa. Można przyjąć, że objęła przynajmniej kilka pokoleń, a korzeniami sięgała wczesnych lat powojennych. Jest porównywalna z takimi czynnikami zmiany społeczno-kulturowej jak zjednoczenie Polski dzielnicowej, odzyskanie niepodległości po I wojnie światowej, a nawet chrzest Polski. Każdy z tych czynników stwarzał nową rzeczywistość: polityczną, gospodarczą, kulturową, religijną i społeczną. Każdy dotyczył całego 
narodu, a jednocześnie nie pozostawał bez znaczenia dla innych krajów, zwłaszcza europejskich.

W niniejszych badaniach uwzględniono percepcję konsekwencji transformacji ustrojowej w Polsce dla kraju i świata, wyrażającą się w ocenach dwóch wybranych grup pokoleniowych: pokolenia dorosłych pracowników socjalnych oraz ich dzieci - młodzieży uczęszczającej do szkół ponadgimnazjalnych. Na podstawie analizy zaprezentowanej w tym opracowaniu sformułowane zostały następujące wnioski:

1. Analiza percepcji skutków transformacji ustrojowej w Polsce dla różnych obszarów funkcjonowania życiowego Polaków wykazała stosunkowo dużą zgodność w ocenach pokolenia rodziców i ich dzieci, bowiem tylko w jednym z ocenianych obszarów wpływu różnice te osiągnęły poziom istotności statystycznej (w zmianie sytuacji bytowej Polaków), a w dwóch innych zbliżyły się do tego poziomu (w zmianie stosunków między ludźmi w Polsce oraz zmianie moralności Polaków).

2. Analiza percepcji konsekwencji transformacji ustrojowej w Polsce dla zmian o zasięgu globalnym wykazała, że zarówno w jednej, jak i w drugiej grupie pokoleniowej średnie obliczone dla tych zmian były bardzo niskie, kształtowały się na poziomie poniżej wartości 2,0. Badana młodzież najniżej oceniała wpływ transformacji ustrojowej w Polsce na zmianę nasilenia konfliktów zbrojnych na świecie, a najwyżej - na zmiany techniczno-cywilizacyjne w świecie i rozwój nauki. Pokolenie rodziców także najczęściej dostrzegało pozytywny wpływ polskiej transformacji na zmiany techniczno-cywilizacyjne w świecie i rozwój nauki, a najrzadziej - na zmianę nasilenia konfliktów zbrojnych na świecie oraz zmianę losu chorych i niepełnosprawnych.

3. Transformacja ustrojowa w Polsce zapoczątkowała zmiany, które dotyczyły bezpośrednio całego społeczeństwa polskiego, zarówno zwolenników jak i przeciwników nowego ładu społeczno-politycznego i ekonomicznego. We współczesnym zglobalizowanym świecie tak głębokie zmiany jednego kraju nie mogą pozostawać bez znaczenia dla innych państw danego kontynentu, a pośrednio także całego świata. Takie przekonanie wyraziła większość zarówno dorosłych Polaków, jak i polskiej młodzieży.

Kolejne pokolenia różnią się pod względem preferencji wartości i postaw odnoszących się do wszystkich obszarów funkcjonowania życiowego, przy czym różnice te mogą być większe bądź mniejsze. $\mathrm{Z}$ analiz zawartych w tym artykule wynika, że pod względem ocen konsekwencji transformacji ustrojowej z 1989 roku dwa pokolenia Polaków różnią się tylko nieznacznie. Niezależnie od tego, czy dane pokolenie uczestniczyło w dokonanych wówczas zmianach, czy też zna je tylko z przekazów pośrednich, każde z nich uznało w zdecydowanej większości, 
że w konsekwencji transformacji Polakom żyje się lepiej, co dotyczy warunków bytowych, ale i uczestnictwa w kulturze i nauce. Co więcej, obydwa pokolenia łączy również poczucie dumy narodowej wyrażające się przekonaniem, że polska transformacja wywarła wpływ na pozytywne zmiany o zasięgu ogólnoświatowym.

\section{LITERATURA}

Adamczyk M., 2014, Grupa pokoleniowa jako czynnik różnicujący typ wytwarzanego kapitału społecznego w Polsce. „Zeszyty Naukowe KUL”, 1(225), 55-80.

Chałasiński J., Jakubczak F. (oprac.), 1972, Młode pokolenie wsi Polski Ludowej. Drogi awansu w mieście. Warszawa, Ludowa Spółdzielnia Wydawnicza.

Chałasiński J., 1984, Młode pokolenie chłopów, t. I. Warszawa, Ludowa Spółdzielnia Wydawnicza.

Garewicz J., 1983, Pokolenie jako kategoria socjofilozoficzna. „Studia Socjologiczne”, $1,75-87$.

Giddens A., 2006, Socjologia. Warszawa, Wydawnictwo Naukowe PWN.

Gnitecki J., 2007, Wstęp do ogólnej metodologii badań w naukach pedagogicznych, t. 2. Tworzenie wiedzy o edukacji w naukach pedagogicznych. Poznań, Wydawnictwo UAM.

Krüger H.-H., 2007, Metody badań w pedagogice. Gdańsk, GWP.

Krzywicki L. (oprac.), 1933, Pamiętniki bezrobotnych. Warszawa, Instytut Gospodarstwa Społecznego.

Krzywicki L. (oprac.), 1935, Pamiętniki chłopów. Warszawa, Instytut Gospodarstwa Społecznego.

Mannheim K., 1992, Ideologia i utopia. Lublin, Wydawnictwo Test.

Ossowska M., 1986, Socjologia moralności. Zarys zagadnień. Warszawa, Wydawnictwo Naukowe PWN.

Pilch T., 2010, Strategia badań ilościowych. W: S. Palka (red.), Podstawy metodologii badań w pedagogice. Gdańsk, GWP.

Sztompka P., 2005, Socjologia. Analiza społeczeństwa. Kraków, Wydawnictwo Znak.

THE IMPORTANCE OF GENERATIONAL CHANGE FOR ASSESSING THE CONSEQUENCES OF THE POLISH TRANSFORMATION

Abstract: The study is of a literature and empirical character. The literature section introduces the problems of the fall of communism in Poland, considered in terms of social phenomena and 
processes. The research section presents the results of research concerning the assessment of the impact of the fall of communism in Poland on the fate of the country and the world. The assessments were made by two generations of respondents; the presentation of results takes into account the differences resulting from generational affiliation. An original procedure was used in the research together with the author's research tool. The results showed that the majority of Poles are convinced about the positive impact of the Polish transformation both on the fate of the country and changes on a global scale. The generational differences in the assessments made were small, only sporadically shaped at the level of statistical significance. Only a few of the respondents expressed negative consequences of the fall of communism in Poland and they mostly represented the adult generation, while the youth more often than adults did not make any assessments. It can be concluded on the basis of these results that Poles are convinced of the legitimacy of changes after 1990, and their opinions on the global significance of these changes are an expression of a sense of pride in the achievements of their own nation.

Keywords: generation, social change 